$[\mathrm{CL}]$

\title{
Ivory Coast microtektite strewn field: description and relation to the Jaramillo geomagnetic event
}

\author{
B.P. Glass ${ }^{a}$, Dennis V. Kent ${ }^{b}$, David A. Schneider ${ }^{b}$ and L. Tauxe ${ }^{c}$ \\ ${ }^{a}$ Department of Geology, University of Delaware, Newark, DE 19716, USA \\ "Lamont-Doherty Geological Observatory, Columbia University, Palisades, NY 10964, USA \\ Scripps Institution of Oceanography, University of California, San Diego, La Jolla, CA 92093, USA
}

(Received January 4, 1991; revision accepted June 17, 1991)

ABSTRACT

\begin{abstract}
During the present study the Ivory Coast microtektite layer was found in cores from five equatorial Atlantic sites, bringing the total number of Ivory Coast microtektite-bearing cores to eleven. The strewn field appears to be restricted to between $9^{\circ} \mathrm{N}$ and $12^{\circ} \mathrm{S}$ latitude. There is a general increase in the concentration of microtektites towards the Bosumtwi crater, which is generally thought to be the source of the Ivory Coast tektites. The relationship between the onset of the Jaramillo subchron and the Ivory Coast microtektite layer has been investigated in six cores. A plot of the difference in depth between the base of the Jaramillo subchron and the microtektite layer versus sediment accumulation rate was used to determine the average post-depositional remanent magnetization (PDRM) acquisition depth and the age difference between the onset of the Jaramillo subchron and the deposition of the microtektites. Assuming that the PDRM acquisition depth does not vary with sediment accumulation rate, we find that the average PDRM acquisition depth is $7 \mathrm{~cm}$ and that the microtektites were deposited approximately $8 \mathrm{ky}$ after the onset of the Jaramillo subchron. This indicates that the impact responsible for the Ivory Coast tektites and microtektites could not be causally related to the geomagnetic reversal at the base of the Jaramillo subchron.
\end{abstract}

\section{Introduction}

Ivory Coast tektites were first reported in 1934 [1]. The tektites were found in a region of about $40 \mathrm{~km}$ radius around the town of Quallé. Additional collections were made in 1963 [2] and 1965 [3], but the total number collected remains small ( 200). Barnes [4] and Cohen [5] suggested that the Ivory Coast tektites might have been derived from the Bosumtwi (or Ashanti) Crater to the east, in Ghana. This conclusion is supported by age data [6-10], isotope studies [11-13], and compositional data $[14,15]$ (for additional references, see Jones [15]).

Glass spherules, thought to be Ivory Coast microtektites, were found in deep-sea deposits from the equatorial Atlantic in 1967 [16]. This conclusion was later supported by major element $[17,18]$ and trace element [19] data and age data [18,20].

Most authors now accept the hypothesis, first proposed by Spencer [21], that tektites (and microtektites) are terrestrial surface material that was melted and ejected by the hypervelocity impact of an extraterrestrial body (e.g., [22,23]).

The close association of the Australasian and Ivory Coast microtektite layers with, respectively, the Brunhes/Matuyama reversal boundary and the base of the Jaramillo subchron has led some workers to suggest a possible causal relationship between some tektite events (i.e., impacts) and geomagnetic reversals $[10,24,25]$. Paleomagnetic studies [26] of the Ries impact crater in Germany, which has been suggested [5] as the source of the Czechoslovakian tektites, indicate that the lake sediments just above the fallback breccia appear to be normally magnetized, whereas the fallback breccia produced at the time of the impact is reversely magnetized. According to Pohl [26], deposition of the lake sediments began within a few hundred years after crater formation. Thus the 
data suggest that a reversal took place shortly after the impact that produced the Ries crater and possibly the Czechoslovakian tektites.

Based on the apparent association between several impacts and geomagnetic reversals, Muller and Morris [27] proposed a model to explain how impact events might trigger reversals (see also [28]). In a more recent study, Burns [29] found that the Australasian tektite event preceded the Brunhes / Matuyama reversal by $11.8 \pm 5.6 \mathrm{ky}$. Because a geomagnetic reversal does not take place instantaneously, but over a period of 5-9 ky (e.g., [30]), Burns' [29] finding does not preclude a causal relationship between the Australasian tektite event and the Brunhes/Matuyama reversal.

The exact relationship between the Ivory Coast microtektites and the Jaramillo subchron has been difficult to determine. Mankinen et al. [31] give an age of $\sim 0.97 \mathrm{my}$ for the onset of the Jaramillo subchron. Koeberl et al. [32] report a ${ }^{40} \mathrm{Ar} /{ }^{39} \mathrm{Ar}$ age of $1.05 \pm 0.11 \mathrm{my}$ for the Ivory Coast tektites, which is generally consistent with previous age estimates based on the $\mathrm{K} / \mathrm{Ar}$ and fission-track methods. Thus, the best estimates for the age of the Jaramillo subchron and the Ivory Coast tektites and microtektites suggest that the Ivory Coast tektite event may have preceded the Jaramillo subchron. However, within the quoted errors, the Ivory Coast tektites could be the same age as or younger than the onset of the Jaramillo subchron.

Magnetostratigraphic work on deep-sea cores by Glass and Zwart [18] confirmed that there is a close association of the Ivory Coast microtektites with the onset of the Jaramillo.

Jones et al. [33] interpreted a magnetic anomaly associated with the Bosumtwi crater, which is generally believed to be the source of the Ivory Coast tektites, as being due to normally magnetized fallback breccia within the crater. If that interpretation is correct, then the Bosumtwi crater formed during a time of normal polarity (i.e., during the Jaramillo subchron) and therefore could not have been the cause of the reversal that initiated the Jaramillo subchron. This conclusion was supported by Schneider and Kent [34] who estimated that the microtektite event occurred approximately $30 \mathrm{ky}$ after the onset of the Jaramillo subchron, based on the magnetostratigraphy of an Ivory Coast microtektite-bearing core (V27-239).

In order to determine more precisely the rela- tionship between the Ivory Coast microtektite layer and the Jaramillo subchron, we sought additional deep-sea sediment cores that contained both the microtektite layer and the Jaramillo subchron. In the course of this study, the Ivory Coast microtektite layer was found in five additional cores (Table 1), of which four have a reasonably well defined Jaramillo subchron (i.e., ODP664C, ODP664D, RC13-210 and RC13-213).

\section{Methods}

During Leg 108 of the Ocean Drilling Program in 1986 , nine sites were cored within or close to the Ivory Coast microtektite strewn field. Based on shipboard biostratigraphic and paleomagnetic data, we were sent samples from five sites (sites $660 \mathrm{~A}, 661 \mathrm{~A}, 662 \mathrm{~B}, 663 \mathrm{~B}$ and 664C) which were thought to extend through the Jaramillo subchron. Samples were later requested from four additional sites (ODP Sites 664D, 665A, 665B and 667A). In all cases the initial sampling interval was $20 \mathrm{~cm}$. Subsequent sampling reduced the sampling interval to a maximum of $10 \mathrm{~cm}$ in the section of primary interest at each site. During the study of these samples the paleomagnetic stratigraphy of three Lamont-Doherty Geological Observatory (L-DGO) piston cores from the vicinity of the strewn field became available (cores RC13-210, $\mathrm{RC13-213}$ and $\mathrm{RC16-75).} \mathrm{These} \mathrm{cores} \mathrm{were} \mathrm{sam-}$ pled at $5 \mathrm{~cm}$ intervals through the section of interest.

The magnetic stratigraphies of the ODP cores were determined by measuring archive halves at 3 $\mathrm{cm}$ intervals using a $2 \mathrm{G}$ Enterprises three-axis cryogenic magnetometer with a through-bore sample access. The archive cores were demagnetized to $5 \mathrm{mT}$. The working half of one of these (664D) was later sampled with a " $u$ " channel and measured at a $1 \mathrm{~cm}$ spacing. These data were supplemented by discrete sample measurements (see Tauxe et al. [35] for a more detailed discussion of procedures). The magnetic stratigraphies of the L-DGO cores were determined according to the methodology described in Schneider and Kent [34].

In order to search for the microtektites, samples were disaggregated and wet-sieved into two size fractions $(63-125 \mu \mathrm{m}$ and $>125 \mu \mathrm{m})$. When necessary, a portion (or all) of the carbonate was dissolved using dilute $\mathrm{HCl}$ in order to facilitate 


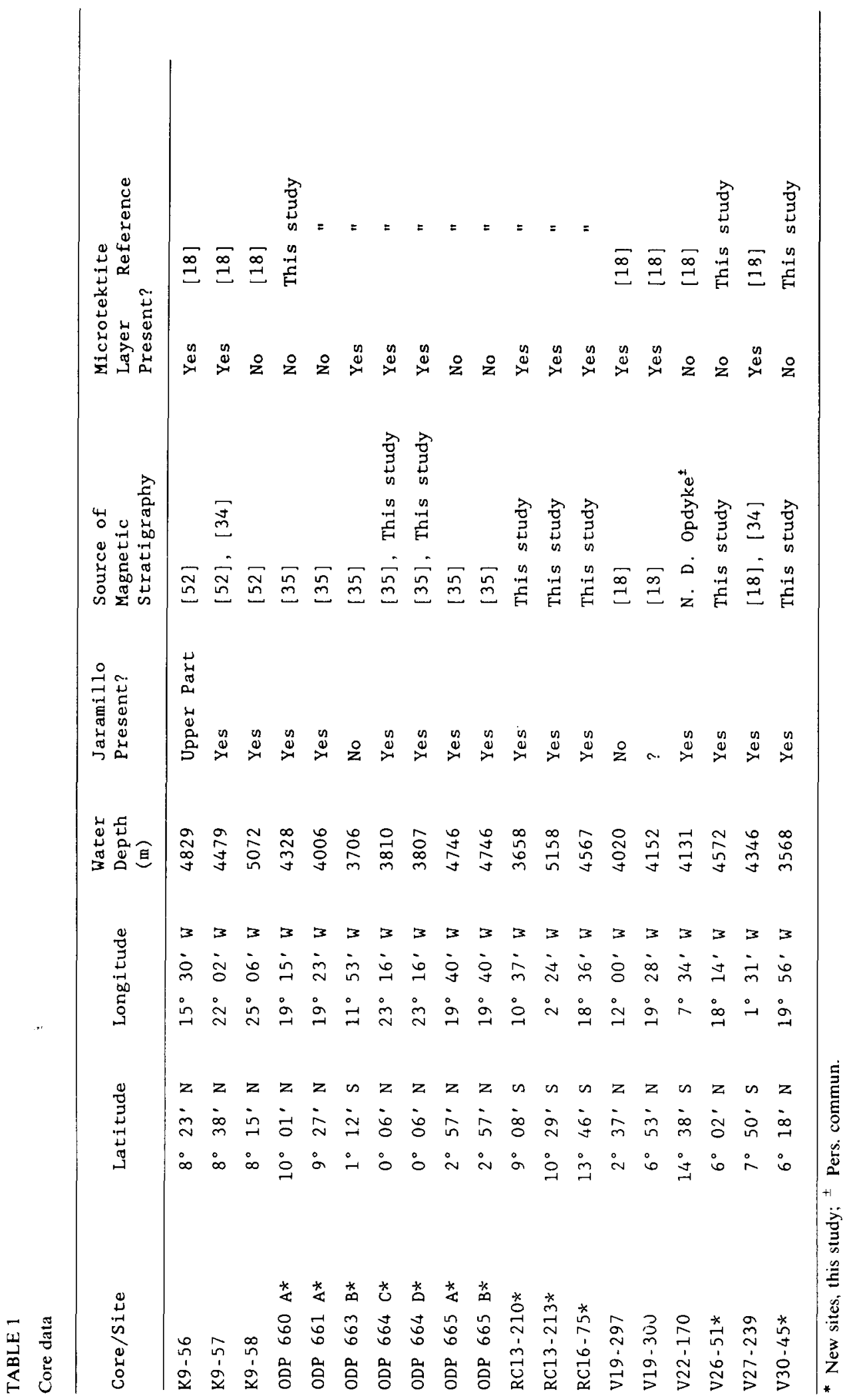


the search. Both size fractions were searched for microtektites using a binocular microscope with magnification of up to $50 \times$. Identifications of the microtektites were based on their shape (generally spherical), glassy appearance, isotropic nature under cross polarizers, and major element compositions. Major element compositions of selected specimens were determined using energy dispersive X-ray analysis (see Glass and Koeberl [36] for a description of the procedure used).

\section{Results and discussion}

To date, nineteen cores from the equatorial Atlantic Ocean between $17^{\circ} \mathrm{N}$ and $29^{\circ} \mathrm{S}$ have been studied that contain the Ivory Coast microtektite layer and/or the Jaramillo subchron (Table
$1,[18])$. Ten of these cores contain the Ivory Coast microtektite layer and six of the ten also contain a well-defined Jaramillo subchron (Table 1). The sections searched and the sample intervals and sizes are given in Table 2 for those cores in which no microtektites were found.

\subsection{Composition}

The major oxide compositions of 26 microtektites from ODP Leg 108 sites and LamontDoherty cores RC13-210 and RC13-213 are similar to the major oxide compositions of Ivory Coast microtektites from previously identified cores (Table 3). Like previously studied Ivory Coast microtektites, these microtektites are characterized by low $\mathrm{SiO}_{2}$ contents (generally $<70 \%$ ) and high $\mathrm{MgO} / \mathrm{CaO}$ and $\mathrm{Na}_{2} \mathrm{O} / \mathrm{K}_{2} \mathrm{O}$ ratios. These char-

TABLE 2

Interval searched and sample spacing for cores found not to contain the Ivory Coast microtektite layer

\begin{tabular}{|c|c|c|c|c|c|c|}
\hline \multirow[b]{2}{*}{ Core/Site } & \multicolumn{2}{|c|}{ Jaramil1o Subchron } & \multirow{2}{*}{\multicolumn{2}{|c|}{$\begin{array}{l}\text { Interval } \\
\text { Searched } \\
(\mathrm{cm})\end{array}$}} & \multirow{2}{*}{$\begin{array}{l}\text { Sample } \\
\text { Spacing } \\
(\mathrm{cm})\end{array}$} & \multirow{2}{*}{$\begin{array}{l}\text { Sample } \\
\text { Size } \\
\left(\mathrm{cm}^{3}\right)\end{array}$} \\
\hline & $\begin{array}{l}\text { Top } \\
(\mathrm{cm})\end{array}$ & $\begin{array}{l}\text { Bottom } \\
(\mathrm{cm})\end{array}$ & & & & \\
\hline ODP 660A & 2290 & 2460 & $\begin{array}{l}2170 \\
2440 \\
2470\end{array}$ & $\begin{array}{l}-2440 \\
-2470 \\
-2660\end{array}$ & $\begin{array}{l}20 \\
10 \\
20\end{array}$ & $\begin{array}{l}6 \\
6 \\
6\end{array}$ \\
\hline ODP $661 \mathrm{~A}$ & 1480 & 1600 & $\begin{array}{l}1270 \\
1570 \\
1610\end{array}$ & $\begin{array}{l}-1570 \\
-1610 \\
-1650\end{array}$ & $\begin{array}{l}20 \\
10 \\
20\end{array}$ & $\begin{array}{l}6 \\
6 \\
6\end{array}$ \\
\hline ODP $665 A$ & 1930 & 2100 & $\begin{array}{l}1860 \\
2050 \\
2130\end{array}$ & $\begin{array}{l}-2050 \\
-\quad 2110\end{array}$ & $\begin{array}{l}20 \\
10 \\
--\end{array}$ & $\begin{array}{l}6 \\
6 \\
6\end{array}$ \\
\hline ODP $665 \mathrm{~B}$ & 1690 & 1870 & $\begin{array}{l}1620 \\
1830 \\
1880\end{array}$ & $\begin{array}{l}-1830 \\
-1880 \\
-1920\end{array}$ & $\begin{array}{l}20 \\
10 \\
20\end{array}$ & $\begin{array}{l}6 \\
6 \\
6\end{array}$ \\
\hline $\operatorname{RC} 16-75$ & 425 & 430 & $\begin{array}{l}411 \\
430 \\
451\end{array}$ & $\begin{array}{r}-421 \\
-\quad 440\end{array}$ & $\begin{array}{r}10 \\
5 \\
--\end{array}$ & $\begin{array}{l}8 \\
8 \\
8\end{array}$ \\
\hline V26-51 & 607 & 648 & $\begin{array}{r}0 \\
400 \\
700\end{array}$ & $\begin{array}{r}400 \\
-\quad 700 \\
-\quad 830\end{array}$ & $\begin{array}{l}50 \\
20 \\
10\end{array}$ & $\begin{array}{l}8 \\
8 \\
8\end{array}$ \\
\hline V30-45 & 714 & 757 & $\begin{array}{r}0 \\
550 \\
710 \\
780 \\
800\end{array}$ & $\begin{array}{lr}- & 550 \\
- & 710 \\
- & 780 \\
- & 800 \\
- & 1700\end{array}$ & $\begin{array}{l}50 \\
20 \\
10 \\
20 \\
50\end{array}$ & $\begin{array}{l}8 \\
8 \\
8 \\
8 \\
8\end{array}$ \\
\hline
\end{tabular}


TABLE 3

Major oxide composition of microtektites and possible microtektites from ODP Leg 108 sites and Lamont-Doherty cores (RC13-210, RC13-213) and from previously identified Ivory Coast microtektite-bearing cores

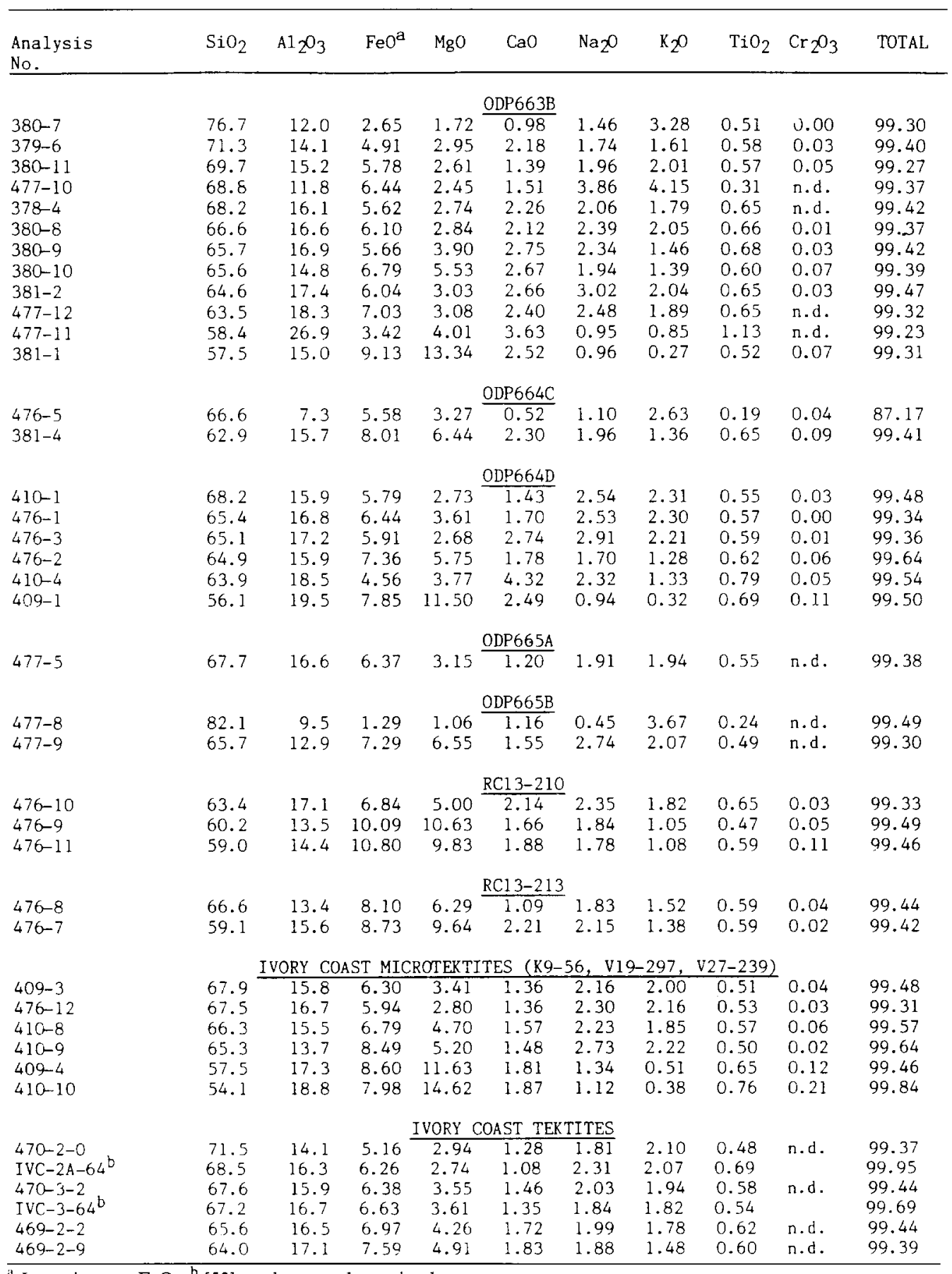

aron given as $\mathrm{FeO} ;{ }^{b}[53]$; n.d. $=$ not determined. 
acteristics distinguish them from otlfer tektite and microtektite groups.

Some of the glasses have unusual compositions for Ivory Coast microtektites which could indicate a greater range in composition than that previously known. Only two glass particles were recovered from ODP 665B. One appears to be a normal Ivory Coast microtektite (Table 3 , analysis No. 477-9), but the other has very high $\mathrm{SiO}_{2}$ for an Ivory Coast microtektite. One of the glass particles from ODP 664C (analysis No. 476-5) has a low total oxide content (suggesting hydration) and a low $\mathrm{Al}_{2} \mathrm{O}_{3}$ content. In contrast, a glass fragment from ODP 663B (No. 477-11) has a high $\mathrm{Al}_{2} \mathrm{O}_{3}$ content. Another glass particle from ODP $663 \mathrm{~B}$ (No. 477-10) has high $\mathrm{Na}_{2} \mathrm{O}$ and $\mathrm{K}_{2} \mathrm{O}$ and may actually be volcanic in origin. One of the glass particles from ODP 664D (No. 410-4) is unusual because it contains low $\mathrm{FeO}$ and high $\mathrm{CaO}$ compared with other Ivory Coast microtektites with similar $\mathrm{SiO}_{2}$ contents.

Other than the exceptions discussed above, the microtektites from ODP Leg 108 sites and Lamont-Doherty cores RC13-210 and RC13-213 appear to be typical Ivory Coast microtektites.

\subsection{Description of the strewn field}

Nineteen cores that contain Ivory Coast microtektites and/or the Jaramillo subchron define the strewn field (Table 1 and Fig. 1). The discovery of Ivory Coast microtektites in cores RC13-210 and RC13-213 and in cores from ODP Site 664 indicates that the strewn field extends farther south and farther west, respectively, than previously thought [18]. It appears that the strewn field does not extend below about $12^{\circ} \mathrm{S}$. This is supported by additional cores in the South Atlantic, with good magnetic stratigraphies, that do not contain Ivory Coast microtektites (see [18]). Ivory Coast microtektites have not been found in cores taken north of $9^{\circ} \mathrm{N}$ (Fig. 1) (see also [18]); otherwise the pattern north of the equator is quite complicated and the eastern and western limits are not well defined. The complicated pattern north of the equator could indicate a ray pattern. On the other hand, the distribution of microtektites within the strewn field might have been affected by other factors such as surface and bottom currents and/or solution. Additional cores from this region must be studied before the shape and extent of the

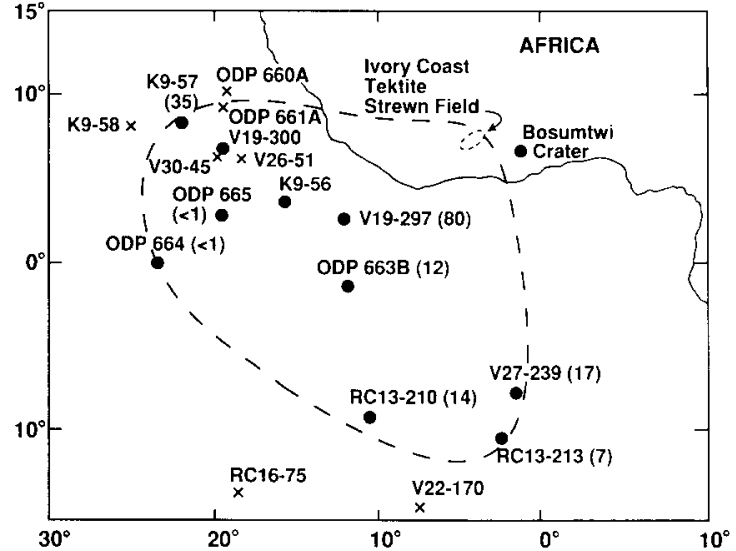

Fig. 1. The Ivory Coast tektite strewn field. Cores containing microtektites indicated by dots (the number in parenthesis is the estimated number of microtektites larger than $125 \mu \mathrm{m}$ in diameter $/ \mathrm{cm}^{2}$ ). The microtektite layer was not penetrated in core K9-56, and in core V19-300 the microtektites were scattered over $3 \mathrm{~m}$ of section; therefore, the number of microtektites per unit area could not be determined for these two sites. Cores with well-defined Jaramillo subchron, but no microtektites, are indicated by an " $x$ ".

strewn field can be determined with any confidence.

In general, there is a decrease in the calculated number of microtektites ( $>125 \mu \mathrm{m}$ in diameter) per unit area with distance from the Ivory Coast tektite occurrences on land and in the Bosumtwi crater. Core V19-297, which is from the site closest to the Bosumtwi crater, has the highest concentration; whereas cores taken at ODP Site 664, which is the farthest site from Bosumtwi found to contain microtektites, have the lowest concentration. The concentration data are, therefore, consistent with a source region in the direction of the Bosumtwi crater.

\subsection{Relationship with the Jaramillo subchron}

The paleomagnetic stratigraphies of cores K9-57 and V27-239 and ODP Leg 108 cores are discussed in Schneider and Kent [34] and Tauxe et al. [35], respectively. The magnetic stratigraphies for RC13-210 and RC13-213 are shown in Fig. 2.

The magnetic stratigraphies of cores from ODP Sites $665 \mathrm{~A}$ and $665 \mathrm{~B}$ are well defined [35]; however, only one glass particle was recovered from $665 \mathrm{~A}$ and two from $665 \mathrm{~B}$. The particle from $665 \mathrm{~A}$ was spherical and appears to be an lvory Coast microtektite (Table 3, analysis No. 477-5). It was 
found at a depth of $70-73 \mathrm{~cm}$ in core 3 , section 6 , approximately $39 \mathrm{~cm}$ above the base of the Jaramillo subchron. As previously discussed, one of the glass particles recovered from 665B has much higher $\mathrm{SiO}_{2}$ than other previously identified Ivory Coast microtektites (Table 3, analysis No. 477-8); however, the other particle could be an Ivory Coast microtektite (Table 3, analysis No. 477-9). Both particles were recovered below the base of the Jaramillo event (one was found 1-2 $\mathrm{cm}$ below and the other about $58 \mathrm{~cm}$ below). Because neither Site 665A nor Site 665B contains a well-defined microtektite layer, the data from these sites were not used to determine the relationship between the Ivory Coast microtektite layer and the Jaramillo event.

A well-defined microtektite layer occurs at a depth of about $116 \mathrm{~cm}$ in section 3 , core $4 \mathrm{H}$ of ODP Site 663B; however, no reliable magnetic data were obtained for that site [35]. Furthermore, a slump block occurs at that depth in the core [37]. Thus the data from this site too could not be used to determine the relationship between the Ivory Coast microtektite layer and the Jaramillo event.

The Ivory Coast microtektite layer always occurs within the Jaramillo subchron, and closer to the base than to the top of the subchron (Table 4 and Fig. 3). In order to determine the relative timing of these events, we need to correct for bioturbation of the microtektite layer and the post-depositional remanent magnetization (PDRM) acquisition depth.

Several different models have been proposed to correct for mixing due to bioturbation (e.g. [3844]). Guinasso and Schink [40] suggested a simple way to correct for the downward displacement of an impulse tracer due to bioturbation based on the mean depth of the impulse tracer (e.g., microtektites) distribution. This method was used in this study. The average displacement of the microtektite peak abundance due to bioturbation was found to be only $2 \mathrm{~cm}$, with a maximum of only 4 $\mathrm{cm}$.

Although it has been suspected for some time that geomagnetic reversal boundaries are shifted down in deep-sea sediments [45], the magnitude of the shift is not well known. Recent estimates of the PDRM acquisition (or lock-in) depth range from less than $3 \mathrm{~cm}$ to $1 \mathrm{~m} \mathrm{[46-50].} \mathrm{At} \mathrm{any} \mathrm{given}$ site there is a wide range of possible age differences and PDRM acquisition depths that could explain the difference in depth between an event recorded in the sediment and a geomagnetic reversal boundary. Therefore, unless there is an inde-
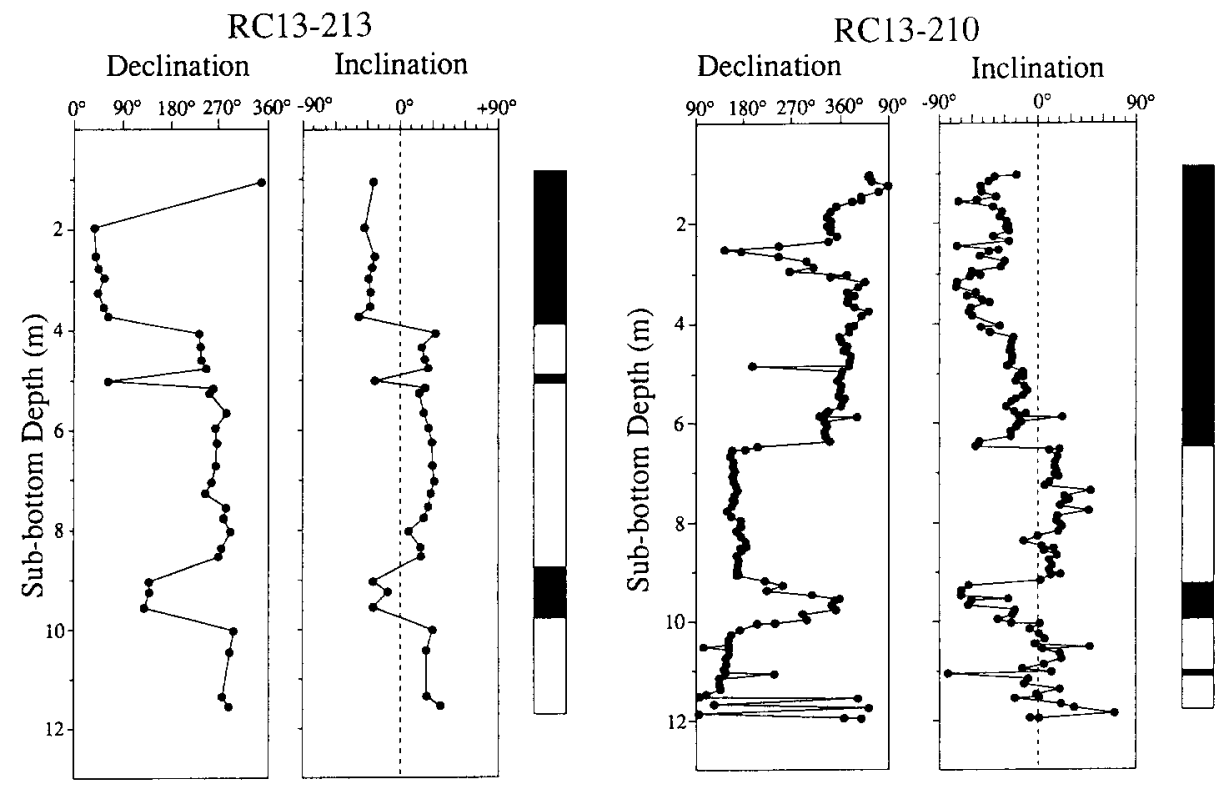

Fig. 2. Magnetic polarity stratigraphy for cores RC13-210 and RC13-213 after AF demagnetization to $30 \mathrm{mT}$. Black indicates normal polarity, white reverse polarity. 


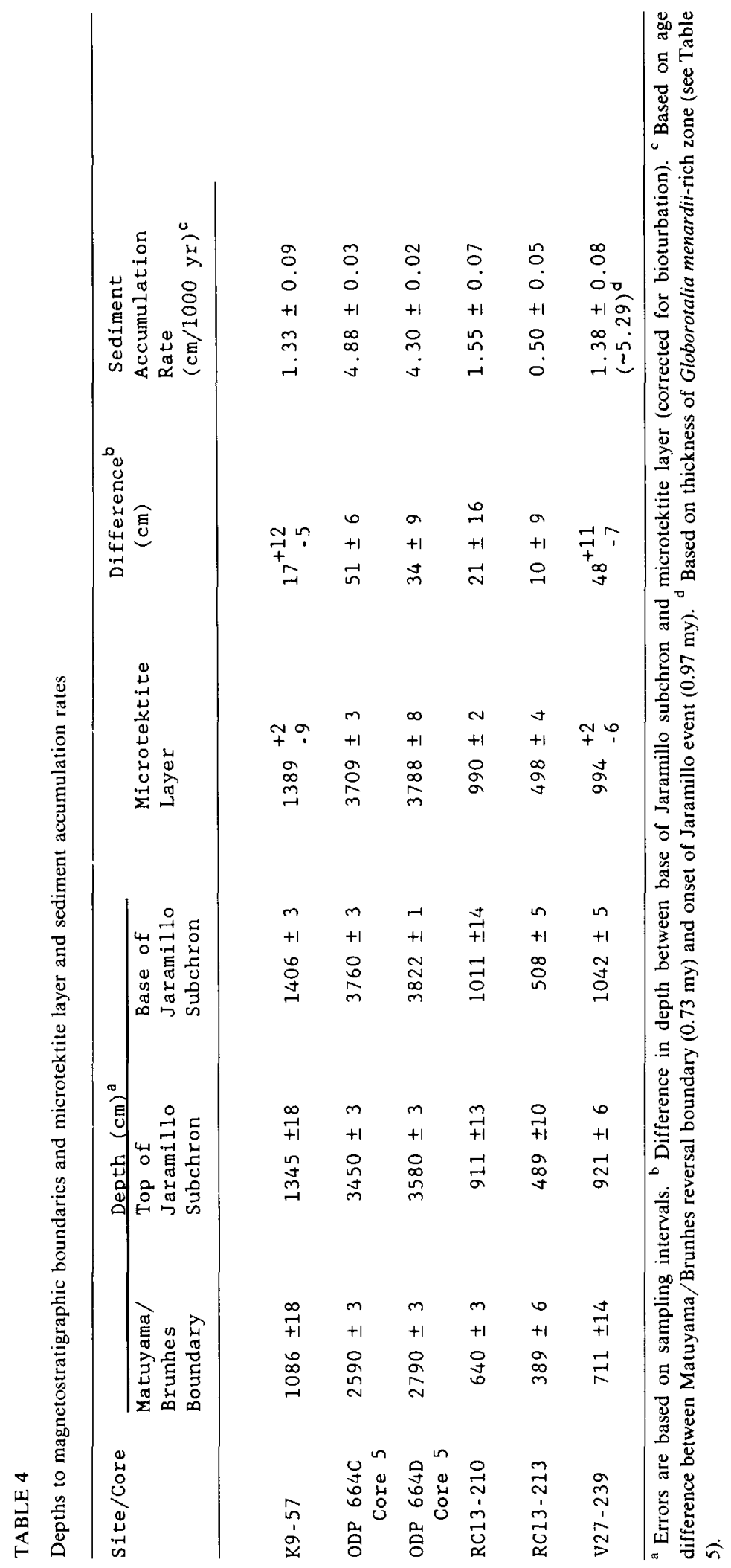


pendent method for determining the PDRM acquisition depth at a site, it is not possible to determine accurately the age difference between the event and the time of the reversal.

Burns [29] has shown, however, that when there are several sites with different sediment accumulation rates that contain a record of both the microtektite event and the reversal it is possible to use the data from all the sites to determine the average PDRM acquisition depth and thus the difference in age between the two events. This can be accomplished by making a plot of the difference in depth between the geomagnetic reversal boundary and the event (e.g., microtektite layer) versus sediment accumulation rate at each site. Assuming that the PDRM acquisition depth does not change systematically with sediment accumulation rate, the best fit through the data points is a line whose intercept with the $y$-axis indicates the average PDRM acquisition depth and whose slope indicates the age difference.

As an illustration, assume that the PDRM acquisiton depth is $10 \mathrm{~cm}$ and that the reversal preceded deposition of the microtektite layer by 10,000 years. Thus, when a reversal occurs it is shifted down a depth of $10 \mathrm{~cm}$ in the sediment and then 10,000 years later the microtektite layer is deposited. If the sediment accumulation rate is $0.5 \mathrm{~cm} / 1000 \mathrm{yrs}$, then $5 \mathrm{~cm}$ of sediment will be deposited between the time of the reversal and the deposition of the microtektite layer. In this case the microtektite layer will be $15 \mathrm{~cm}$ above the reversal and the reversal depth minus the depth of the microtektite layer will be $+15 \mathrm{~cm}$ (point 1 in Fig. 4). If the sediment accumulation rate is 1 $\mathrm{cm} / 1000 \mathrm{yrs}$, then $10 \mathrm{~cm}$ of sediment will be
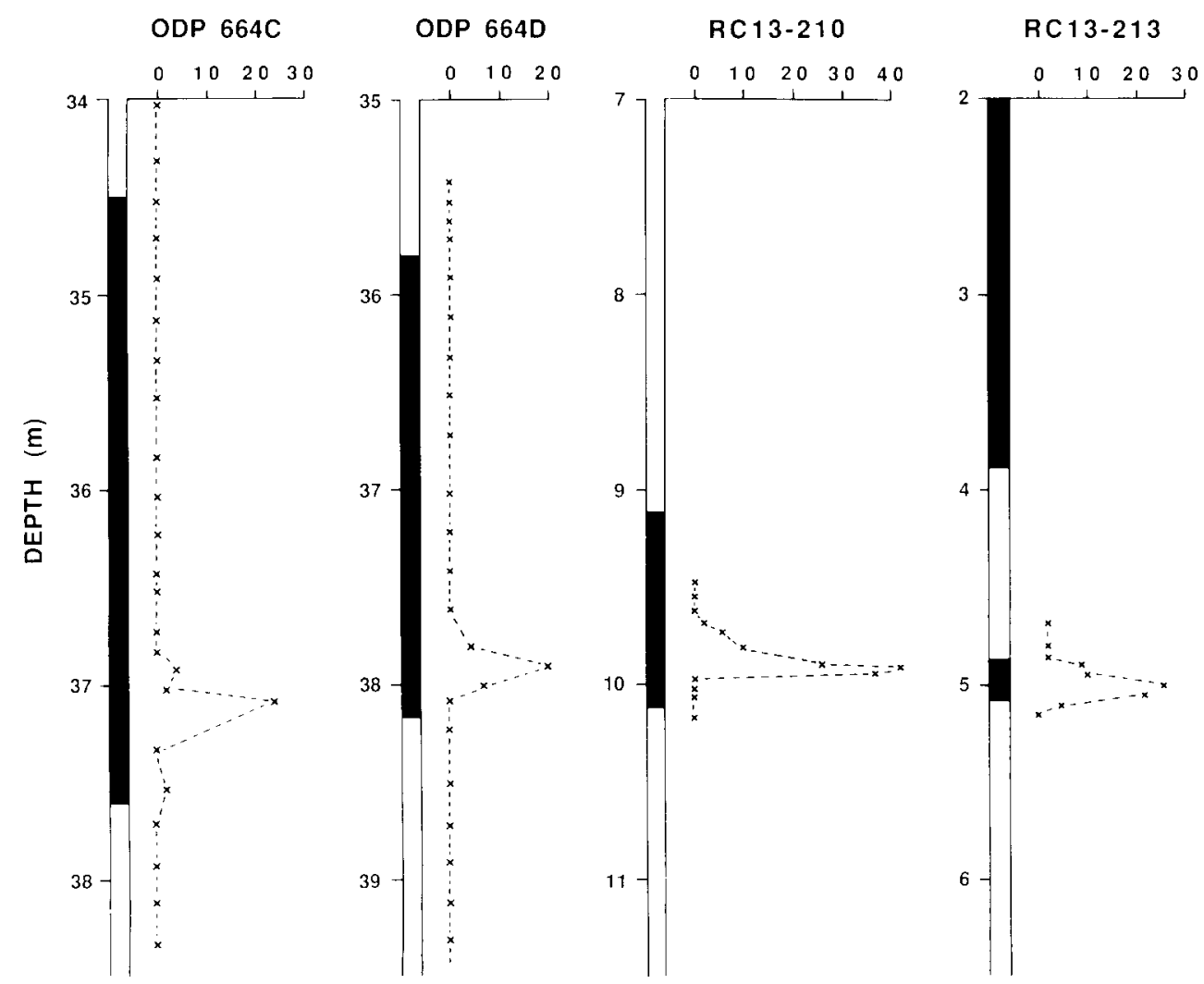

Fig. 3. Relationship between the microtektite layer and the Jaramillo subchron for ODP Sites 664C and 664D and Lamont-Doherty Geological Observatory cores RC13-210 and RC13-213. Normally magnetized section of core indicated by black, reversely magnetized indicated by white. The scale to the top right of each magnetic stratigraphy is the number of microtektites ( $>63 \mu \mathrm{m}$ diameter) $/ 10 \mathrm{~g}$ sample. Magnetic stratigraphies for ODP cores from Tauxe et al. [35]. Magnetic stratigraphies for cores RC13-210 and RC13-213 are shown in Fig. 2. 


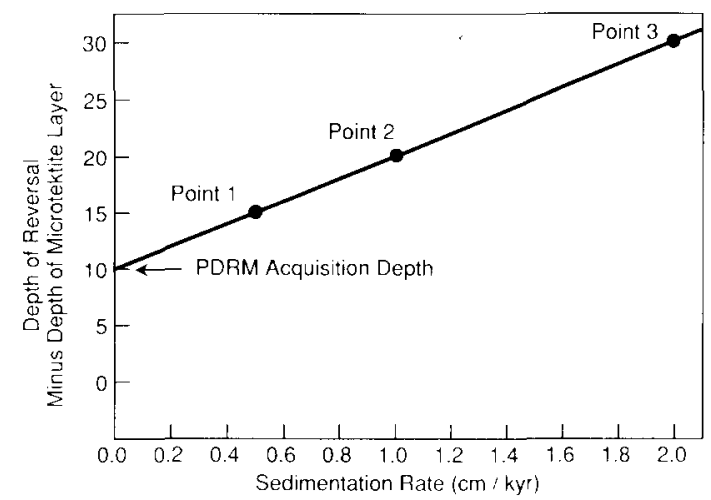

Fig. 4. Depth to a reversal minus depth to a microtektite layer versus sediment accumulation rate for a hypothetical case in which the microtektite layer is deposited 10,000 yrs after the reversal and the PDRM acquisition depth is $10 \mathrm{~cm}$. Because the event occurred after the reversal, the data points define a line with a positive slope. The slope of the line is determined by the age difference and the $Y$-intercept is determined by the PDRM acquisition depth.

deposited between the time of the reversal and deposition of the microtektite layer. Thus, the microtektite layer will be $20 \mathrm{~cm}$ above the reversal boundary (point 2 in Fig. 4). For a sediment accumulation rate of $2 \mathrm{~cm} / 1000 \mathrm{yrs}, 20 \mathrm{~cm}$ of sediment will be deposited between the time of the reversal and deposition of the microtektite layer and the microtektite layer will be $30 \mathrm{~cm}$ above the reversal (point 3 in Fig. 4). A straight line through these points intercepts the $y$-axis at $10 \mathrm{~cm}$, which is the depth of acquisition. The slope of the line is determined by the age difference between the reversal and the microtektite event. The greater the age difference the steeper the slope. If the event preceded the reversal, a plot of the distance between the reversal boundary and the microtektite layer would result in a line with a negative slope. For additional discussion of this method see de Menocal et al. [51].

We now have six cores with reasonably well defined Ivory Coast microtektite layers and Jaramillo subchrons (Table 3). With one exception (V27-239), there is a systematic increase in the distance between the base of the Jaramillo subchron and the Ivory Coast microtektite layer with increasing sediment accumulation rate as calculated for the section between the Brunhes/ Matuyama reversal boundary and the base of the Jaramillo (Table 4 and Fig. 5). The errors given in
Table 4 are based on sampling intervals. The greatest uncertainty is in the sediment accumulation rate estimates, but as discussed below we used some micropaleontological data as an independent check.

The best fit line through the data points, excluding core V27-239, intercepts the $y$-axis at -7 $\mathrm{cm}$. This is the average PDRM acquisition depth. The slope of the line indicates an age difference between the reversal at the base of the Jaramillo subchron and the Ivory Coast microtektite layer of $\sim 8 \mathrm{ky}$ (the age difference can be found by subtracting the $y$-intercept from the difference in depth between the reversal and the microtektite layer at a given sediment accumulation rate and dividing by that sediment accumulation rate). Note that the major effect of correcting for bioturbation is to shift the best fit line up vertically, which increases the apparent PDRM acquisition depth, but which does not affect the age difference (unless the magnitude of the shift due to bioturbation changes systematically with sediment accumulation rate).

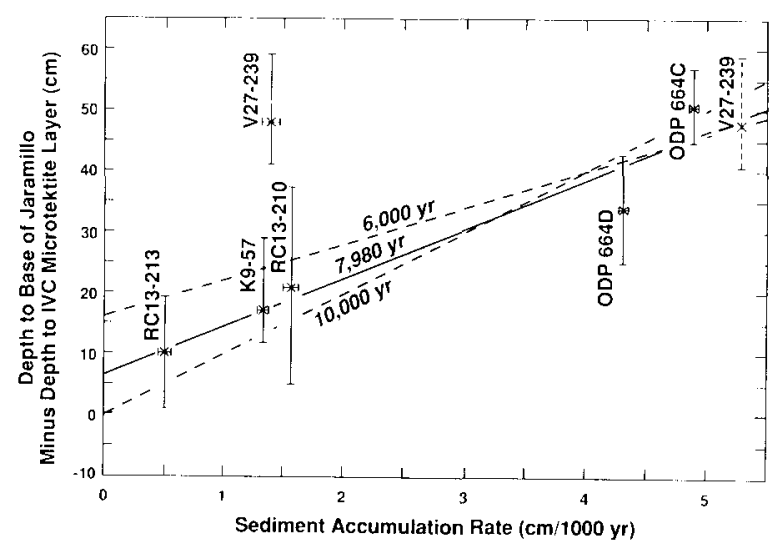

Fig. 5. Depth to base of Jaramillo subchron minus depth to the Ivory Coast microtektite layer versus sediment accumulation rate (see Table 2). Regression analysis indicates that the difference in depth between the base of the Jaramillo and the microtektite layer $=(7.983 \pm 1.343) \times($ sed. acc. rate $)+6.546 \pm$ 5.231 with an $r^{2}$ value of 0.922. Data from V27-239 were not used in the calculation. Dashed lines are lines with the steepest and gentlest slopes that still fit all the data (except V27-239 with a calculated sediment accumulation rate of $1.38 \mathrm{~cm} / \mathrm{kyr}$ ) within the error limits. The steepest line is also constrained by the fact that it should not go below zero at the $y$-intercept, since a negative value on the $y$-intercept would imply that the reversal boundary was shifted up rather than down. 
Within the error limits the $y$-intercept could be as low as $0 \mathrm{~cm}$ or as high as $16 \mathrm{~cm}$, as indicated respectively, by the steepest and gentlest lines, that go through all the data points (Fig. 5). The slopes of these lines indicate an age difference of $10 \mathrm{ky}$ and $6 \mathrm{ky}$, respectively. Thus the average PDRM acquisition depth is $7_{-7}^{+9} \mathrm{~cm}$ and the age difference is $8 \pm 2 \mathrm{ky}$. The positive slope of the best fit line (Fig. 5) indicates that the microtektite layer was deposited after the reversal at the onset of the Jaramillo subchron.

We also calculated the sediment accumulation rate using the top and bottom of the Jaramillo subchron. Although this brackets the sections of interest in each core more closely, it results in larger uncertainties, especially for cores with lower sediment accumulation rates. In spite of the larger errors, the results were similar. Core V27-239 still plots well off the trend of the other cores and therefore the data point from this core was not used to define the best fit line. The $y$-intercept is $-8 \mathrm{~cm}$ and the age difference is $\sim 8 \mathrm{ky}$, but with larger uncertainties. Even if the data point from V27-239 is used in the calculation for the best fit line, the results are similar (i.e., $y$-intercept of 13 $\mathrm{cm}$ and age difference of $7 \mathrm{ky}$ ).

\section{Discussion}

Our findings support Schneider and Kent's [34] conclusion that the Ivory Coast microtek tite layer was deposited after the onset of the Jaramillo subchron, and that, therefore, the impact that produced the Ivory Coast tektites could not have triggered the reversal that initiated the Jaramillo subchron. However, our data indicate that the microtektites were deposited about $8 \mathrm{ky}$ after the onset of the Jaramillo subchron rather than $30 \mathrm{ky}$ after as proposed by Schneider and Kent [34].

Schneider and Kent [34] used core V27-239 to calculate the age difference between the onset of the Jaramillo event and the microtektite layer. However, we found that in this core the distance between the base of the Jaramillo event and the microtektite layer is substantially higher compared with other cores with apparently similar sediment accumulation rates (Fig. 5). There are several possible reasons for this discrepancy: (1) the microtektites in V27-239 could belong to a different (younger) layer, (2) the PDRM acquisition depth was much greater in this core, or (3) the sediment accumulation rate is actually much higher than calculated.

It seems unlikely that the microtektites in core V27-239 belong to a younger event. The core is within the boundary of the strewn field as defined by other Ivory Coast microtektite-bearing cores (Fig. 1), and the microtektites are similar in appearance and composition to other Ivory Coast microtektites [18]. Furthermore, none of the Ivory Coast microtektite-bearing cores has been found to contain two microtektite layers.

If the position of V27-239 on Fig. 5 is the result of a greater PDRM acquisition depth, the acquisition depth would have to be $>30 \mathrm{~cm}$. This is more than four times greater than the average acquisition depth for the other five cores, even though this core is from the same geographic setting and intermediate water depth as the other Ivory Coast microtektite-bearing cores and has a similar lithology (foraminiferal marl).

In his study of the relationship between the Australasian microtektite layer and the Brunhes/ Matuyama reversal boundary, Burns [29] concluded that the PDRM acquisition depth increased with decreasing sediment accumulation rate. His data would suggest that sediment with a sediment accumulation rate of $1.38 \mathrm{~cm} / \mathrm{ky}$ (as calculated for V27-239) should have a PDRM acquisition depth of about $9 \mathrm{~cm}$. De Menocal et al. [51] used the relationship between the oxygen isotopic stage 19.1 and the Brunhes/Matuyama reversal boundary to determine the average PDRM acquisition depth. They found an average acquisition depth of $16 \mathrm{~cm}$, which is within the range obtained in this study without using data from V27-239. Thus, based on previous work, a depth of acquisition of $30 \mathrm{~cm}$ or more, required to make the data from V27-239 compatible with the other Ivory Coast microtektite-bearing cores, appears to be much too high.

It seems, therefore, that the sediment accumulation rate in the lower part of the Jaramillo subchron of core V27-239 is much higher than calculated from the reversal stratigraphy. This conclusion is supported by carbonate abundance data and by some biostratigraphic data. In core V27-239, the highest percentage of carbonate between the Brunhes/Matuyama reversal and the base of the Jaramillo subchron is in the lower half 
of the Jaramillo subchron. This suggests that the highest sediment accumulation rate occurs in the lower part of the subchron.

All of the Ivory Coast microtektite-bearing cores contain a peak in abundance of the Globorotalia menardii complex that straddles the reversal at the base of the Jaramillo subchron. The thickness of the menardii-rich zone is determined by the sediment accumulation rate. Core V27-239 has the thickest menardii-rich zone (Table 5) and therefore should have the highest sediment accumulation rate in this interval. Regression analysis for all the cores, except V27-239, indicates that the thickness of the menardii zone $=(20.98) \times($ sed. acc. rate) +19.09 with an $r^{2}$ value of 0.995 . This relationship indicates that for V27-239 with a menardii-rich zone of $130 \pm 20 \mathrm{~cm}$ the sediment accumulation rate should be $5.29 \pm 0.95 \mathrm{~cm} / \mathrm{ky}$. Using this sediment accumulation rate, core V27239 plots close to the best fit line determined for the other Ivory Coast microtektite-bearing cores (Fig. 5). If Schneider and Kent [34] had used a sediment accumulation rate of $5.3 \mathrm{~cm} / \mathrm{ky}$, they would have obtained an age difference between the base of the Jaramillo subchron and the Ivory
Coast microtektite layer similar to that which we find.

A critical assumption in our model is that PDRM acquisition depth is not proportional to sediment accumulation rate. We believe that this assumption is reasonable because the mixing depth due to bioturbation, which is a factor in determining PDRM acquisition depth, appears to be independent of sediment accumulation rate $[40,54]$. It could be argued, nevertheless, that the microtektite layer was deposited prior to the reversal at the base of the Jaramillo and that the occurrence of the microtektite layer above the reversal is due to the PDRM acquisition depth being proportional to sediment accumulation rate, which would then result in large PDRM acquisition depths at high sediment accumulation rates. We feel that this is unlikely. The Ivory Coast microtektite layer is always above the base of the Jaramillo subchron in cores with sediment accumulation rates ranging by about an order of magnitude $(0.5-4.88 \mathrm{~cm} / \mathrm{ky})$, and the height above increases with sediment accumulation rates. This is in contrast with the Australasian microtektite layer which, although it is generally above the

TABLE 5

Thickness of Globorotalia menardii-rich zone

\begin{tabular}{|c|c|c|c|c|}
\hline \multirow[t]{2}{*}{ Core } & \multicolumn{2}{|c|}{ G. menardii-rich Zone Z $^{ \pm}$} & \multirow[b]{2}{*}{ Thickness $(\mathrm{cm})$} & \multirow{2}{*}{$\begin{array}{l}\text { Sediment } \\
\text { Accumulation } \\
\text { Rate (cm/kyr)* }\end{array}$} \\
\hline & Bottom $(\mathrm{cm})$ & Top $(\mathrm{cm})$ & & \\
\hline $\mathrm{RC} 13-213$ & $525 \pm 5$ & $492 \pm$ & $33 \pm 7$ & 0.50 \\
\hline K9-57 & $1444 \pm 6$ & $1397 \pm$ & $47 \pm 10$ & 1.33 \\
\hline$v 27-239$ & $1090 \pm 10$ & $960 \pm 10$ & $130 \pm 20$ & 1. 38 \\
\hline $\mathrm{RC} 13-210$ & $1022 \pm 5$ & $975 \pm$ & $47 \pm 7$ & 1.55 \\
\hline ODP $664 \mathrm{D}$ & $3880 \pm 10$ & $3770 \pm$ & $110 \pm 20$ & 4.30 \\
\hline ODP $664 \mathrm{C}$ & $3800 \pm 10$ & $3678 \pm$ & $122 \pm 14$ & 4.88 \\
\hline
\end{tabular}


Brunhes/Matuyama reversal boundary, occurs below the reversal in cores with higher sediment accumulation rates. The different relationships between the Ivory Coast and Australasian microtek tite layers and nearest reversal boundaries indicate that the time relationship between the microtektite layers and the respective reversals cannot be the same. Furthermore, if the Ivory Coast microtektite layer were deposited prior to the reversal the PDRM acquisition depth would have to exceed $50 \mathrm{~cm}$ in core V27-239 and in core 5 from Site $664 \mathrm{C}$, where the microtek tite layer is $-50 \mathrm{~cm}$ above the base of the Jaramillo subchron. This is greater than the PDRM acquisition depth measured in two cores using ${ }^{10} \mathrm{Be}$ : Raisbeck [49] found an acquisition depth of $15-20 \mathrm{~cm}$ in a core with a sediment accumulation rate of $2.5 \mathrm{~cm} / 1000 \mathrm{yrs}$ [see also 55] and Aylmer et al. [56] found an acquisition depth of $-30 \mathrm{~cm}$ for a core with a sediment accumulation rate of $8.2 \mathrm{~cm} / 1000 \mathrm{yrs}$.

Mankinen et al. [31] give an age of 0.97 my for the geomagnetic reversal that marks the onset of the Jaramillo subchron. Since the Ivory Coast microtektite layer was deposited approximately 8 ky after the onset of the Jaramillo event, it would appear that the Ivory Coast microtektites were deposited approximately $0.96 \mathrm{my}$ ago. Recent studies indicate that the Ivory Coast tektites and microtektites were formed about $1.04 \pm 0.1$ my ago (Table 6). The Bosumtwi crater, which is generally believed to be the source of the Ivory Coast tektites, has also been dated at about 1 my [5,7-9,11,13-15]. The different age estimates are therefore internally consistent, within the quoted, uncertainties. The different age estimates for the Ivory Coast tektite event and onset of the Jaramillo, although within quoted uncertainties of one another, might suggest a somewhat older age for the lower Jaramillo boundary.

\section{Conclusion}

The extent and geographic shape of the Ivory Coast strewn field is not well established, but

TABLE 6

${ }^{40} \mathrm{Ar}-{ }^{39} \mathrm{Ar}$. K-Ar, and fission-track ages of Ivory Coast tektites and microtektites and Bosumtwi crater glass

\begin{tabular}{lll}
\hline Method & Age $^{1}$ & Source \\
\hline & Ivory Coast Tektites & \\
& $1.05 \pm 0.11$ myr (4) & {$[32]$} \\
K-Ar & $1.2 \pm 0.2$ myr (3) & {$[6]$} \\
& $1.15 \pm 0.15$ myr (10) & {$[57]$} \\
Fission-Track & $0.71 \pm 1.41$ myr (4) & {$[58]$} \\
& $1.01 \pm 0.1$ myr (6) & {$[57]$} \\
& $0.86 \pm 0.06$ myr $(1)$ & {$[32]$} \\
& $1.03 \pm 0.11$ myr ${ }^{39}$ & {$[10]$} \\
Fission-Track & Ivory Coast Microtektites & {$[10]$} \\
K-Ar & $1.09 \pm 0.2$ myr & {$[59]$} \\
& $0.88 \pm 0.13$ myr &
\end{tabular}

${ }^{1}$ Number in parenthesis is number of samples; ${ }^{2}$ corrected for thermal annealing. 
geographic variation in the estimated concentration of microtektites at each deep-sea site is consistent with a source region in the vicinity of the Bosumtwi impact crater. Assuming that the PRDM acquisition depth does not vary with sediment accumulation rate, data from five sites with both a microtektite layer and a well-defined Jaramillo subchron indicate an average PDRM acquisition depth of $7 \mathrm{~cm}$. The data also indicate that the Ivory Coast tektite event took place approximately $8 \pm 2$ ky after the initiation of the Jaramillo event and thus agree with previous conclusions $[33,34]$ that the impact that produced the Bosumtwi crater and the Ivory Coast tektites is not causally related to the magnetic reversal at the beginning of the Jaramillo event.

\section{Acknowledgements}

Ocean Drilling Program core samples were supplied with the assistance of the International Ocean Drilling Program under the guidance of William F. Ruddiman. We thank John W. King and Richard A. Muller for critical reviews of the paper. Lamont-Doherty Geological Observatory (LDGO) core samples were provided by Rusty Lotti of the L-DGO Core Laboratory. This work was partly funded by NSF grants OCE83-14522 (BPG), OCE88-17773 (DVK, DAS) and OCE89-17252 (LT). This is Lamont-Doherty contribution 4811.

\section{References}

1 A. Lacroix, Sur la découverte de tectites à la Côte d'Ivoire, C. R. Acad. Sci. 199, 1539-1542, 1934.

2 W. Gentner, Auf der suche nach Kratergläsern, Tektiten und Meteoriten in Africa, Naturwissenschaften 12, 285-289, 1966.

3 J.M. Saul, Field investigations at Lake Bosumtwi (Ghana) and in the Ivory Coast Tektite Strewn Field, Nat. Geogr. Soc. Res. Rep. 1964 Proj. 201-212, 1969.

4 V.E. Barnes, Tektites, Sci. Am. 205(5), 58-65, 1961.

5 A.J. Cohen, Asteroid- or comet-impact hypothesis of tektite origin: The moldavite strewn-fields, in: Tektites, J.A. O'Keefe, ed., pp. 189-211, Univ. Chicago Press, Chicago, 1963.

$6 \mathrm{~J}$. Zähringer, K-Ar measurements of tektites, in: Radioactive Dating, pp. 289-305, Int. At. Energy Agency, Vienna, 1963.

7 C.C. Schnetzler, W.H. Pinson and P.M. Hurley, Rubidium-strontium age of the Bosumtwi crater area, Ghana, compared with the age of the lvory Coast tektites, Science $151,817-819,1966$.
8 W. Gentner, B. Kleinman and G.A. Wagner, New K-Ar and fission track ages of impact glasses and tektites, Earth Planet. Sci. Lett. 2, 83-86, 1967.

9 P. Kolbe, W.H. Pinson, J.M. Saul and E.W. Miller, Rb-Sr study on country rocks of the Bosumtwi crater, Ghana, Geochim. Cosmochim. Acta 31, 869-875, 1967.

10 J.A. Durrani and H.A. Khan, lvory Coast microtektites: Fission-track ages and geomagnetic reversals, Nature 232 . 320-323, 1971.

11 H.P. Taylor and S.E. Epstein, Oxygen isotope studies of Ivory Coast tektites and impactite glass from the Bosumtwi crater, Ghana, Science 153, 173-175, 1966.

12 J.M. Wampler, D.H. Smith and A.E. Cameron, Isotopic comparison of lead in tektites with lead in earth materials, Geochim. Cosmochim. Acta 33, 1045-1055, 1969

13 H.F. Shaw and G.J. Wasserburg, Age and provenance of the target materials for tektites and possible impactites as inferred from $\mathrm{Sm}-\mathrm{Nd}$ and $\mathrm{Rb}-\mathrm{Sr}$ systematics, Earth Planet. Sci. Lett. 60, 155-177, 1982.

14 C.C. Schnetzler, J.A. Philpotts and H.H. Thomas, Rareearth and barium abundances in Ivory Coast tektites and rocks from the Bosumtwi Crater area, Ghana, Geochim. Cosmochim. Acta 31, 1987-1993, 1967.

15 W.B. Jones, The origin of the Bosumtwi crater, Ghana-an historical review, Proc. Geol. Assoc. 96(3), 275-284, 1985.

16 B.P. Glass, Glassy objects (microtektites?) from deep-sea sediments near the Ivory Coast, Science 161, 891-893, 1968.

17 B.P. Glass, Chemical composition of Ivory Coast microtektites, Geochem. Cosmochim. Acta 33, 1135-1147, 1969.

18 B.P. Glass and P.A. Zwart, The Ivory Coast microtektite strewn field: new data, Earth Planet. Sci. Lett. 43, 336-342, 1979.

19 F.A. Frey, C.M. Spooner and P.A. Baedecker, Microtektites and tektites: a chemical comparison, Science 170 , $845-847,1970$.

20 W. Gentner, B.P. Glass, D. Storzer and G.A. Wagner, Fission track ages and ages of deposition of deep-sea microtektites, Science 168, 359-361, 1970.

21 L.J. Spencer, Origin of tektites, Nature 131, 117-118, 1933.

22 S.R. Taylor, Tektites: A post-Apollo view, Earth Sci. Rev. 9, 101-123, 1973

23 E.A. King, The origin of tektites: A brief review, Am. Sci. 64, 212-218, 1977.

24 B.P. Glass and B.C. Heezen, Tektites and geomagnetic reversals, Nature 214, 373-374, 1967.

25 B.P. Glass, M.B. Swincki and P.A. Zwart. Australasian, Ivory Coast and North American tektite strewn fields: size, mass and correlation with geomagnetic reversals and other earth events, Proc. Lunar Planet. Sci. Conf. 10th, 25352545, 1979.

26 J. Pohl, Palaeomagnetische und gesteinsmagnetische Untersuchungen an der Kernen der Forschungsbohrung Noerdlingen 1973, Geol. Bav. 75, 329-348, 1977.

27 R.A. Muller and D.E. Morris, Geomagnetic reversals from impacts on the earth, Geophys. Res. Lett. 13, 1177-1180, 1986.

28 R.A. Muller and D.E. Morris, Geomagnetic reversals driven by sudden climate changes, Trans. Am. Geophys. Union $70,276,1989$. 
29 C.A. Burns, Timing between a large impact and a geomagnetic reversal and the depth of the NRM acquisition in deep-sea sediments, in: Geomagnetism and Paleomagnetism, F.J. Lowes et al., eds., pp. 253-261, Kluwer, Dordrecht, The Netherlands, 1989.

30 B.M. Clement, D.V. Kent and N.D. Opdyke, BrunhesMatuyama polarity transition in three deep-sea sediment cores, Philos. Trans. R. Soc. A306, 113-119, 1982.

31 E.A. Mankinen, J.M. Donelly-Nolan, C.S. Grommé and B.C. Hearn, Paleomagnetism of the Clear Lake volcanics and new limits on the age of the Jaramillo normal-polarity event, U.S. Geol. Surv. Prof. Pap. 1141, 67-82, 1980.

32 C. Koeberl, R.J. Bottomley, B.P. Glass, D. Storzer and D. York, Geochemistry and age of Ivory Coast tektites (abstract), Meteoritics 24, 287, 1989.

33 W.B. Jones, M. Bacon and D.A. Hastings, The Lake Bosumtwi impact crater, Ghana, Geol. Soc. Am, Bull. 92, 342-349. 1981.

34 D.A. Schneider and D.V. Kent, Ivory coast microtektites and geomagnetic reversals, Geophys. Res. Lett. 17, 163-166, 1990.

35 L. Tauxe, J.-P. Valet, and J. Bloemendal, Magnetostratigraphy of Leg 108 advanced hydraulic piston cores, Proc. ODP, Sci. Results, 108: 429-452, 1989.

36 B.P. Glass and C. Koeberl, Trace element study of highand low-refractive index Muong Nong-type tektites from Indochina, Meteoritics 24, 143-146, 1989.

37 W.F. Ruddiman and T.R. Janecek, Pliocene-Pleistocene biogenic and terrigenous fluxes at equatorial Atlantic sites 662, 663, and 664, ODP Sci. Results, 108: 211-240, 1989.

38 W.H. Berger and G.R. Heath, Vertical mixing in pelagic sediments, J. Mar. Res. 26, 134-143, 1968.

39 W.F. Ruddiman and L.K. Glover, Vertical mixing of icerafted volcanic ash in North Atlantic sediments, Geol Soc Am. Bull. 83, 2817-2836, 1972.

40 N.L. Guinasso and D.R. Schink, Quantitative estimates of biological mixing rates in abyssal sediments, J. Geophys. Res. 80, 3032-3043, 1975.

41 W.H. Berger, R.F. Johnson, and J.S. Killingley, "Unmixing" of the deep-sea record and the deglacial meltwater spike, Nature 269, 661-663, 1977.

42 E. Bard, M. Arnold, J. Duprat, J. Moyes and J.-C. Duplessy, Reconstruction of the last deglaciation: Deconvoluted records of $\mathrm{O}-18$ profiles, micropaleontological variations and accelerator mass spectrometric 14-C dating, Climat. Dyn. I, $101-112,1987$.

43 T.-H. Peng and W.S. Broecker, The impacts of bioturbation on the age difference between benthic and planktonic foraminifera in deep-sea sediments, Nucl. Instrum. Meth. Phys. Res. B5, 346-352, 1984.

44 J.A. Robbins, A model for particle-selective transport of tracers in sediments with conveyor belt deposit feeders, $J$. Geophys. Res. 91, 8542-8558, 1986.
45 N.D. Watkins, Short-period geomagnetic polarity events in deep-sea sedimentary cores, Earth Planet. Sci. Lett. 4, 341349, 1967.

46 K.L. Verosub. Depositional and postdepositional processes in the magnetization of sediments, Rev. Geophys. Space Phys. 15, 129-143, 1977.

47 N. Niitusuma, Zone magnetization model and depth lag of NRM in deep-sea sediments, Rock Magn. Paleogeophys. 4 $65-71,1977$.

48 Y. Hamano, An experiment on the post-depositional remanent magnetization in artificial and natural sediments, Earth Planet. Sci. Lett. 51, 221-232, 1980.

49 G.M. Raisbeck, F. Yiou, D. Bourles and D.V. Kent, Evidence for an increase is cosmogenic ${ }^{10} \mathrm{Be}$ during a geomagnetic reversal, Nature 315, 315-317, 1985.

$50 \mathrm{C}$. Constable and L. Tauxe. Paleo-intensity in the pelagic realm: marine sediment data compared with archaeomagnetic and lake sediment records, Geophys. J.R. Astr. Soc. 90, 43-59, 1987.

51 P.B. de Menocal, W.F. Ruddiman and D.V. Kent. Depth of post-depositional remanence acquisition in deep-sea sediments: a case study of the Brunhes/Matuyama reversal and oxygen isotopic stage 19.1, Earth Planet. Sci. Lett. 99. 1-13, 1990.

52 W.F. Ruddiman, Pleistocene sedimentation in the equatorial Atlantic: stratigraphy and faunal paleoclimatology, Geol. Soc. Am. Bull. 82, 283-302, 1971.

53 F. Cuttitta, M.K. Carron and C.S. Annell, New data on selected Ivory Coast tektites, Geochim. Cosmochim. Acta 36, 1297-1300, 1972.

54 D.J. DeMaster and J.K. Cochran, Particle mixing rates in deep-sea sediments determined from excess ${ }^{210} \mathrm{~Pb}$ and ${ }^{32} \mathrm{Si}$ profiles, Earth Planet. Sci. Lett. 61, 257-271, 1982.

55 B.M. Clement and D.V. Kent. A southern hemisphere record of the Matuyama-Brunhes polarity reversal, Geophys. Res. Lett. 18, 18-84, 1991.

56 D. Aylmer, M. Guyton, G.F. Herzog, B.M. Clement, J. Klein and R. Middleton. Beryllium-10 contents of sediments associated with the Matuyama-Brunhes geomagnetic reversal (abstract). Trans. Am. Geophys. Union 69, 341. 1988.

57 W. Gentner, D. Storzer and G.A. Wagner, Das alter von Tektiten und verwandten Gläsern. Naturwissenschaften 56 , 255-260. 1969.

58 R.L. Fleischer, P.B. Price and R.M. Walker, On the simultaneous origin of tektites and other natural glasses, Geochim. Cosmochim. Acta 29,161-166, 1965.

59 W. Gentner, H.J. Lippolt and O. Müller, K-Ar-Alter des Bosumtwi-Kraters in Ghana und die chemische Beschaffenheit seiner Gläser, Z. Naturforsch. 19a, 150-153, 1964. 